\title{
Present Status and Future Trends of Natural-Derived Compounds Targeting T Helper (Th) 17 and Microsomal Prostaglandin E Synthase-1 (mPGES-1) as Alternative Therapies for Autoimmune and Inflammatory-Based Diseases
}

\author{
Anella Saviano ${ }^{1}$, Federica Raucci ${ }^{1}$, Gian Marco Casillo ${ }^{1}$, Chiara Indolfi ${ }^{1}$, Alessia Pernice ${ }^{1}$, \\ Carmen Foreste ${ }^{1}$, Asif Jilani Iqbal ${ }^{1,2} \mathbb{D}$, Nicola Mascolo ${ }^{1, *}$ and Francesco Maione ${ }^{1, *}$ (i) \\ 1 ImmunoPharmaLab, Department of Pharmacy, School of Medicine and Surgery, \\ University of Naples Federico II, Via Domenico Montesano 49, 80131 Naples, Italy; \\ nella.1993@hotmail.it (A.S.); federica.raucci@unina.it (F.R.); gianmarcocasillo@virgilio.it (G.M.C.); \\ chiara_indolfi@hotmail.it (C.I.); alessiapernice.ap@gmail.com (A.P.); carmenforeste@gmail.com (C.F.); \\ A.J.Iqbal@bham.ac.uk (A.J.I.) \\ 2 Institute of Cardiovascular Sciences (ICVS), College of Medical and Dental Sciences, \\ University of Birmingham, Birmingham B15 2TT, UK \\ * Correspondence: nicola.mascolo@unina.it (N.M.); francesco.maione@unina.it (F.M.); \\ Tel.: +39-081-678-412 (N.M.); +39-081-678-429 (F.M.)
}

Academic Editors: Karel Šmejkal and Bruno Botta

Received: 1 November 2020; Accepted: 17 December 2020; Published: 18 December 2020

\begin{abstract}
Several natural-based compounds and products are reported to possess anti-inflammatory and immunomodulatory activity both in vitro and in vivo. The primary target for these activities is the inhibition of eicosanoid-generating enzymes, including phospholipase A2, cyclooxygenases (COXs), and lipoxygenases, leading to reduced prostanoids and leukotrienes. Other mechanisms include modulation of protein kinases and activation of transcriptases. However, only a limited number of studies and reviews highlight the potential modulation of the coupling enzymatic pathway COX-2/mPGES-1 and Th17/Treg circulating cells. Here, we provide a brief overview of natural products/compounds, currently included in the Italian list of botanicals and the BELFRIT, in different fields of interest such as inflammation and immunity. In this context, we focus our opinion on novel therapeutic targets such as COX-2/mPGES- 1 coupling enzymes and Th17/Treg circulating repertoire. This paper is dedicated to the scientific career of Professor Nicola Mascolo for his profound dedication to the study of natural compounds.
\end{abstract}

Keywords: BELFRIT; immunity; mPGES-1; natural compounds; Th17

\section{Introduction}

The Belgian decree on botanicals, published 20 years ago, was the prototype of legislation and regulatory practice used in several European countries. In 1997, Belgium was one of the first countries to introduce a notification procedure and scientific risk evaluation by an Advisory Commission. Contextually, the authorities of Belgium, France, and Italy, each assisted by renowned scientific experts, decided to develop a common approach to evaluating botanicals [1]. As a first step, the three parties drafted a standard list of traditionally used plants safe to use in food supplements, commonly known as the BELFRIT project or BELFRIT list [2,3]. This evolved with the support of the European Commission and Member States and now guarantees the safety, quality, and effectiveness to health promoting 
prosperities of food supplements. Most other Member States acknowledge the importance of European Union (EU) harmonization in this "self-growing" area [4-6].

Modern medicine makes use of many plant-derived products/compounds as the basis for pharmaceutical drugs [7]; and quite often it applies modern standards of effectiveness testing to herbs and medicines derived from natural sources, performs high-quality clinical trials and uses standards for purity or dosage [8]. In this scenario, many botanicals are used in both food supplements and nutraceuticals, and yet a precise, unique, and standardized definition/s and procedure/s are still missing.

In this opinion paper, we provide a current state of the art about the anti-inflammatory and immunomodulatory properties of natural-derived compounds (including nutraceuticals, functional food, and dietary supplements) targeting microsomal prostaglandin E synthase-1 (mPGES-1) and the T helper 17 cells (Th17) and regulatory T-cells (Treg) axis, in order to provide a scientific rationale for their potential therapeutic use. Further investigation, in both pre-clinical and clinical fields, are required to provide in-depth evaluation of these botanicals and their bioactive components in the context of autoimmune and inflammatory-based diseases for health-promoting and disease-preventing purposes.

Nutraceuticals, functional foods, and dietary supplements have been known to exert beneficial effects against a variety of disease conditions [9-11]. Several medicinal plants and their isolated components have also been identified to possess health-promoting properties [12]. Moreover, a varied diet containing certain phytochemicals or introduced through supplementation have shown potential antioxidant, anti-inflammatory, and immunomodulatory benefit $[13,14]$. Therefore, the role of natural products and food is essential in maintaining and/or improving immune function $[15,16]$. Functional foods are those enriched or enhanced that provide health benefits beyond essential nutrients when consumed at efficacious levels as part of a varied diet. These mainly include berries, fermented dairy products, green tea, garlic, citrus fruits, and other herbal formulations [17-19]. In contrast the term "dietary supplement" describes a broad and different category of products (mainly containing vitamin C, vitamin D, minerals, omega-3 fatty acid, docosahexaenoic acid, etc.) that we eat or drink to support good health and supplement the diet. While nutraceuticals are food components, such as polyphenols, flavonoids, carotenoids, saponins, sulfides, which are derived from food sources with extra health benefits in addition to fundamental nutritional value [20-24].

These products could work both at the cellular and molecular level by triggering immune cells, up-regulating immune-related genes, and manipulating the systemic immune system, thereby providing natural immunotherapeutic options. These cellular and molecular mechanisms of natural products are essential to define the possible molecular and cellular targets, which could pave the way for discovering novel natural products/compounds exerting the immune-boosting effects $[25,26]$.

\section{Selected Studies and Inclusion and Exclusion Criteria}

All studies were selected through a Medline-PubMed search using different combination of terms or keywords such as Th17, COX-2, mPGES-1, medicinal plants, and natural compounds/products. We have identified only original articles in English that evaluated pre-clinical studies, in vivo rodents models, and isolated and/or well-characterized compounds/extracts from all articles. Studies that analyzed natural substances purchased commercially were not excluded in this work. The next selection was to consider reports in which the method adopted used a natural compound in a well-established disease. The final selection criteria was choosing medicinal plants according to their presence in the Italian list of botanicals and the BELFRIT list.

\section{Natural Compounds Targeting COX-2/mPGES-1/PGE 2 Cascade in Inflammatory-Based Diseases}

Inflammation is a complex protective mechanism against noxious stimuli of chemical, physical, and/or biological origin, characterized by molecular and cellular defensive responses aimed at resolution of ongoing inflammation and restoration of tissue integrity [27-29]. However, the persistence 
of inflammatory inducers and the alteration of processes directed to homeostasis restoration can lead to the onset of chronic inflammation [30,31]. Inflammatory processes are generally associated with the innate immune system, but scientific evidence has shown that innate and adaptive immune cells collectively orchestrate the inflammatory response and that adaptive immune components are also involved in the production of memory cells that can sustain the chronic nature of inflammation-driven by the innate arm [32]. During the past decade, considerable progress has been made in understanding the cellular and molecular events in the acute inflammatory response and the role primary mediators have in infection and tissue injury [33]. Every early immunity "battle" begins with neutrophils, quickly recruited to sites of inflammation for an early response against the noxious stimulus under close control of several endogenous mediators [34]. This phlogistic scenario correlates with a transient increase of pro-inflammatory factors including (i) cytokines such as the interleukin (IL)- 1 family (IL-1 $\alpha / \beta$ ), IL-6, and tumor necrosis factor- $\alpha$ (TNF- $\alpha$ ) that are involved in the early stages of inflammatory and immune processes and warn the host to induce an inflammatory reaction against pathogens [35]; (ii) chemokines for the control of leukocyte extravasation and chemotaxis towards the affected tissues; (iii) the complement fragments (C3a, C4a, and C5a also known as anaphylatoxins) that promote granulocyte and monocytes recruitment and induce mast-cell degranulation [36]; and (iv) prostaglandins (PGs), in particular $\mathrm{PGE}_{2}$, one of the principal lipid mediators of the Arachidonic acid cascade [37]. The first sign of recovery is the switch from PGs (pro-inflammatory lipid mediators) to lipoxins and resolvins (anti-inflammatory lipid mediators); indeed, it inhibits the recruitment of neutrophils and promotes the recruitment of monocytes, restoring homeostatic conditions [38,39].

In the last few years, in the context of acute inflammation, the scientific community has focused the spotlight on mPGES-1 enzyme that acts as a crucial regulator in the terminal steps of $\mathrm{PGE}_{2}$ production from intermediate $\mathrm{PGH}_{2}$ [40]. The baseline expression of mPGES-1 in different tissues is low, but in response to inflammatory stimuli and cytokines such as lipopolysaccharide (LPS), IL-1 $\beta$, TNF- $\alpha$, and IL-17A, mPGES-1 is up-regulated and functionally coupled with COX-2 to mediate pro-inflammatory $\mathrm{PGE}_{2}$ production [41-44]. This elevation in lipid mediators is implicated in the pathogenesis of several inflammatory diseases such as gouty arthritis, rheumatoid arthritis (RA), and atherosclerosis [45-47].

Selective inhibition of downstream mPGES-1 [48] for a specific reduction in $\mathrm{PGE}_{2}$ production is proposed as a safer alternative compared with nonsteroidal anti-inflammatory drugs (NSAIDs) [49,50]. A variety of compounds which target $\mathrm{mPGES}-1$ have been described in the literature and are summarized in Figure 1 [51-54]. Of particular interest is baicalin, a bioactive flavone extracted from the root of Scutellaria baicalensis Georgi. It has been reported that baicalin and, its aglycone baicalein not only suppress the overexpression of pro-inflammatory mediators such as nitric oxide (NO), PGE $2, \mathrm{TNF} \alpha$, IL-1 $\beta$, and IL-6 [55,56] but also inhibit the expression of inducible enzymes COX-2 and inducible nitric oxide synthase (iNOS) [57]. Similarly, the main component of turmeric Curcuma longa has been reported as an efficacious agent against both $\mathrm{PGE}_{2}$ production, COX-2 expression [58], and Matrix Metalloproteinase (MMPs) secretion [59]. 


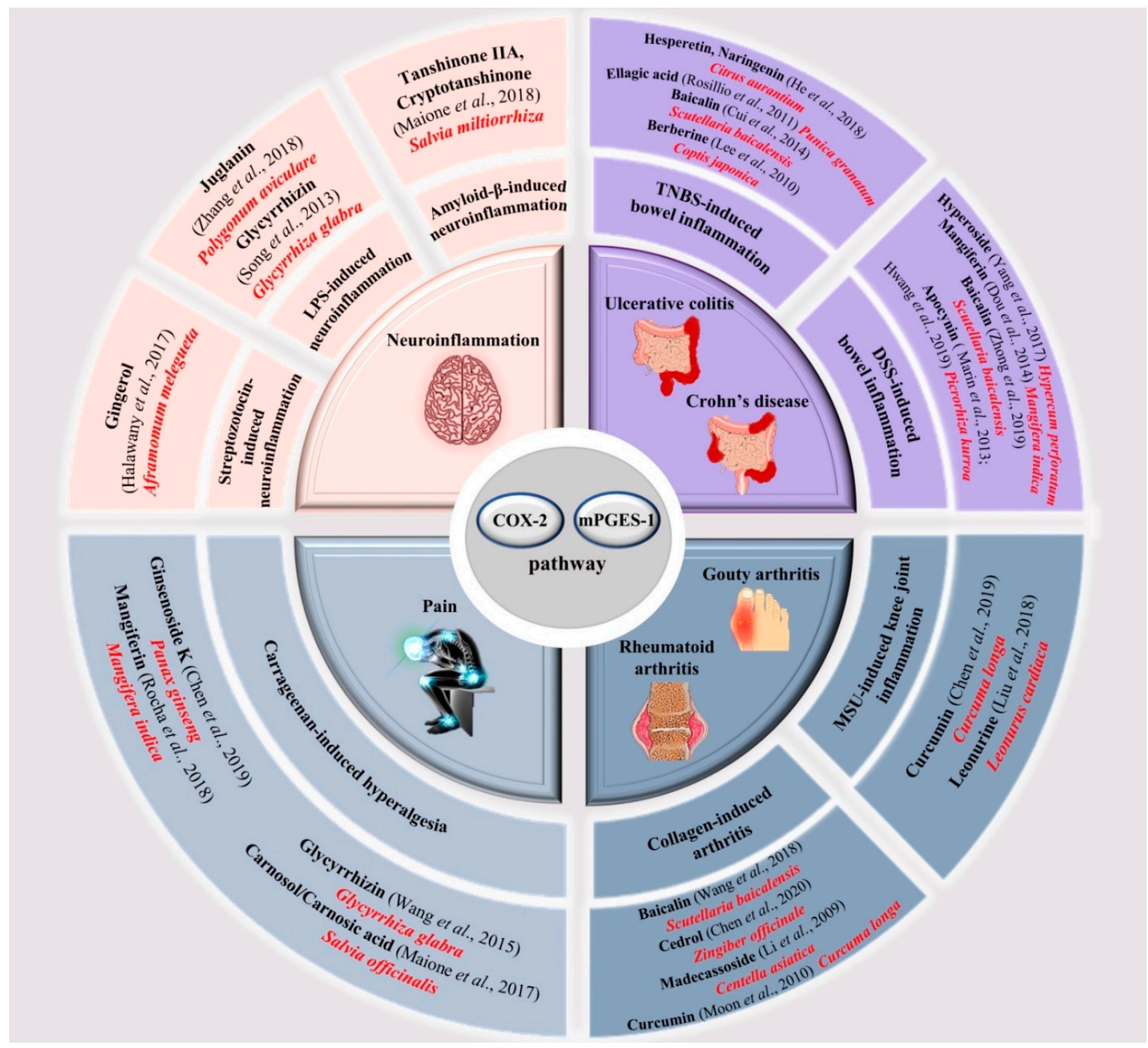

Figure 1. Schematic representation of natural compounds (black bold), by different botanical sources (in red) targeting COX-2/mPGES-1 pathway as alternative therapies for different inflammatory-related diseases. The figure, also, shows the pre-clinical models (black bold), where these active components have been tested with related bibliographic references.

Furthermore, polyphenols, such as naringenin and hesperetin from Citrus aurantium [60], ellagic acid from Punica granatum [61], apocynin from Picrorhiza kurroa [62,63], hyperoside from Hypericum perfoaratum [64], mangiferin from Mangifera indica [65], and alkaloids as berberine (from Coptis japonica) are all capable of attenuating the severity and extension of intestinal-inflammatory injuries via inhibition of neutrophil infiltration, pro-inflammatory proteins COX-2, iNOS, and nuclear factor kappa-light-chain-enhancer of activated B cells (NF- $\mathrm{kB}$ ) activation [66]. Notably, mangiferin also presents analgesic properties due to its ability to reduce pain via $\mathrm{PGE}_{2}$ reduction [67].

A series of in vivo studies found that cedrol, from Zingiber officinale [68], leonurine from Leonurus cardiaca [69], and madecassoside, triterpenoid isolated from Centella asiatica [70], can effectively alleviate inflammatory response through the inhibition of inflammatory pathway COX-2/mPGES-1/5-Lipoxigenase (5-LO) and the up-regulation of anti-inflammatory molecule IL-10.

Moreover, recent work examining the actions of glycyrrhizin (from Glycyrrhiza glabra) [71,72], cryptotanshinone and tanshinone IIA (from Salvia miltiorrhiza Bunge) [73], juglanin (a natural compound derived from the crude Polygonum aviculare) [74], and gingerol (from Aframomum melegueta) [75], in neuroinflammation and nociception, indicate that these natural compounds are potential therapeutic agents in neurodegenerative diseases and painful conditions. 
Finally, the anti-inflammatory and analgesic properties of carnosol, carnosic acid (diterpenoids isolated from Salvia Officinalis) [76] and ginsenoside K (saponins from Panax ginseng) [77] have been intensively described for their ability to modulate pathways involved in inflammation and painful syndromes, including COX-2, mPGES-1 and 5-LO.

These findings pave the way for the use of these botanical-derived compounds as novel anti-inflammatory and analgesic agents targeting COX-2/mPGES-1 pathway.

\section{Natural Compounds Targeting Th17/Treg Axis in Immune-Mediated Inflammatory Diseases}

Considering inflammation from a "cellular point of view", although neutrophils and macrophages have traditionally been looked upon as dominant cell types during the resolution phase, accessory cells such as Th17 and Treg have more recently emerged as important players during resolution. They may link innate and adaptive immune systems [78]. CD4 T cells regulate several immune answers in order to fight against different disease-causing noxious stimuli. The binding of $\mathrm{T}$ cell receptor (TCR) to the peptide-major histocompatibility complex (MHC) activates naïve CD4 T cells that differentiate into effectors cells, including Th17 and Treg [79,80]. Th17, which express the transcription factor retinoic acid receptor-related orphan receptor $\gamma \mathrm{t}(\mathrm{ROR} \gamma \mathrm{t})$, arbitrate immune responses against extracellular bacteria, fungi, and viruses [81]. They produce IL-17, IL-22, and IL-23, stimulate many cell types to recruit neutrophils, and promote inflammation at the site of infection [82]. Consequentially, therapeutic strategies directed to neutralizing these cytokines utilizing monoclonal antibodies have shown encouraging results [46,83-87]. By contrast, Tregs express the transcription factor forehead box P3 (Foxp3) and produce anti-inflammatory cytokines like IL-10 and transforming growth factor- $\beta$ (TGF- $\beta$ ) which inhibit immune responses to control immune homeostasis. These two classes of T cells subsets have opposing roles during inflammatory and immune responses: Th17 can cause, while Treg suppress autoimmune and inflammatory-based diseases [88]. Moreover, Th17 and Treg share a common signaling pathway mediated by TGF- $\beta$, but the external milieu present during activation determines these cells' polarisation [89-91]. Considering the "plasticity" of the differentiation process and since in inflammatory states each cell type can convert to the other, it is not unexpected that the equilibrium between Th17/Treg is critical for pathogenesis, prognosis, and therapy of several autoimmune diseases [92-94].

Indeed, the Th17/Treg ratio is increased in patients with psoriasis, inflammatory bowel disease (IBD), RA [95], and multiple sclerosis (MS) [96].

In Figure 2, we have summarized the broad panel of natural compounds which could potentially modulate Th17/Treg function and prove potentially useful in preventing and/or treating different immune-mediated inflammatory diseases $[78,93,97]$.

In vivo pre-clinical studies suggest that green tea and its active ingredient, epi-gallocatechin gallate (EGCG), may effectively improve the symptoms and inflammatory conditions of autoimmune diseases $[98,99]$. EGCG is also viewed as an anti-inflammatory agent [100] due to its inhibitory effect on the release of IL-6 and IL-17 [101] and the regulation of the Th17/Treg balance [102].

Baicalin, from Scutellaria baicalensis, has been shown to effectively reduced inflammation and tissue damage in colitis, and modulate Th17/Treg imbalance in the colon, ameliorating colorectal inflammation [103]. On the other hand, baicalin downregulated the levels of Th17-related cytokines (IL-17 and IL-6), that provoked chronic inhibition of autophagy and induction of claudin-2 expression, leading to apoptosis and dysregulated epithelial barrier function with subsequent gut dysbiosis and intestinal diseases [104]. These findings highlight a novel immunomodulatory role of baicalin not only in bowel inflammation [105] but also in asthma [106,107] and arthritis [108].

In addition, glycyrrhizin (or glycyrrhizic acid), from Glycyrrhiza glabra, with a corticosteroid-like structure, has been shown to possess several beneficial pharmacological activities, including anti-asthmatic effects [109] and anti-inflammatory activity [110], acting on the Th17/Treg balance and regulating the immune response in different models of chronic inflammation. Noteworthy are mangiferin [111] and neomangiferin [112], main active constituents of Mangifera indica, that decreased 
the proportion of Th17 and the levels of IL-17A, while increasing the balance of Treg and the expression of anti-inflammatory IL-10.

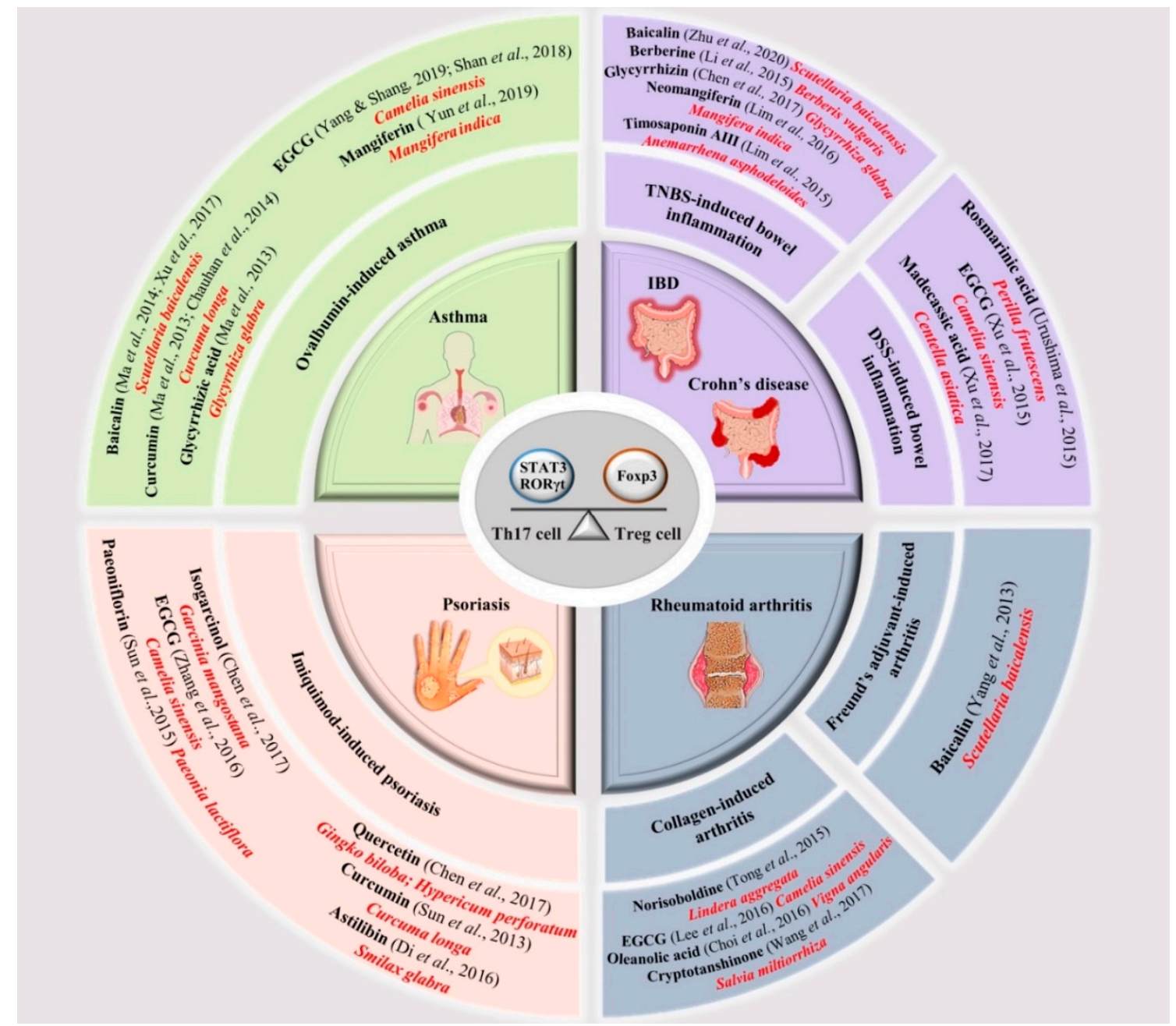

Figure 2. Schematic representation of natural compounds (black bold), by different botanical sources (in red) targeting Th17/Treg ratio as alternative therapies for different autoimmune-based diseases. The figure, also, shows the pre-clinical models (black bold), where these active components have been tested with related bibliographic references.

Th17 and Treg populations are also affected by other polyphenols: curcumin (from Curcuma longa) [113] and quercetin (from Gingko biloba and Hypericum perforatum) attenuatelevels of TNF- $\alpha$, IL-6 [114] and IL-17 [115], associated with the downregulation of NF-kB [116].

Additionally, cryptotanshinone from Salvia miltiorrhiza [117], oleanolic acid isolated from Vigna angularis [118] and norisoboldine, the main active ingredient of the dry root of Lindera aggregata [119], were proven to have anti-arthritic effects, decreasing inflammation and joint destruction.

Taken together, these findings, in addition to the other medicinal plants and their active components such as berberine (from Breberis vulgaris) [120], rosmarinic acid (from Perilla frutescens) [121], timosaponin AIII (from Anemarrhena asphodeloides) [122], madecassic acid (from Centella asiatica) [123], isogarcinol (from Garcinia mangostana) [124], astilbin (from Smilax Glabra) [125] and paeoniflorin (from Paeonia lactiflora) [126], shown in Figure 2, highlight the important role natural compounds could play in the treatment of the most common autoimmune diseases, through their ability to act on Th17/Treg ratio. 


\section{Conclusions and Future Prospect}

European legislation for food supplements and nutraceuticals is not fully harmonized and not adapted to meet current challenges. In this context, the Belgian, French, and Italian authorities have decided to develop a common approach for evaluating botanicals in the BELFRIT project providing harmonization in terms of identification and classification of medicinal plants used in food supplement and/or nutraceuticals. However, in the BELFRIT list, there are only a few and fragmented pieces of information regarding the natural products and compounds targeting COX-2/mPGES- 1 coupling enzymes and Th17/Treg repertoire. In this regard, the information reported here (in particular for those secondary plant's metabolites targeting both pathways, Figure 3) highlights the need for further detailed studies, including mechanism exploration, safety profile, and clinical trials to discover clinically useful drugs and therapeutic targets in widespread pathologies related to inflammatory-based and autoimmune-related diseases.

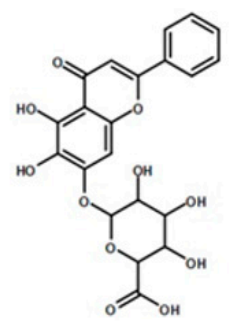

Baicalin<smiles>COc1cc(/C=C/C(=O)CC(=O)/C=C/c2ccc(O)c(OC)c2)ccc1O</smiles>

Curcumin

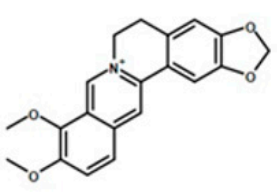

Berberine

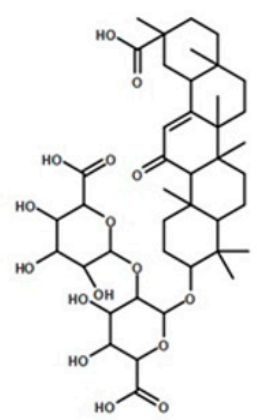

Glycyrrhizin

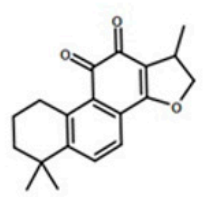

Cryptotanshinone

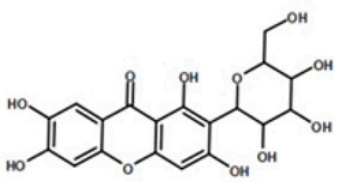

Mangiferin

Figure 3. Chemical structures of most significant secondary metabolites targeting both COX-2/mPGES-1 pathway and Th17/Treg axis.

Author Contributions: A.S., F.R., G.M.C., C.I., A.P., and C.F. drafted the manuscript and figures. A.J.I., N.M., and F.M. wrote and revised the manuscript. All authors have read and agreed to the published version of the manuscript.

Funding: This research was funded by MIUR (PRIN 2017; 2017A95NCJ/2017A95NCJ_002, “Stolen molecules-Stealing natural products from the depot and reselling them as new drug candidates"). A.S. and F.R. are supported by University of Naples Federico II PhD scholarship. A.J.I. is supported by a Birmingham Fellowship.

Conflicts of Interest: This article has been conducted and written in the absence of any commercial or financial relationships that could be construed as a potential conflict of interest.

\section{References}

1. Cousyn, G.; Dalfrà, S.; Scarpa, B.; Geelen, J.; Anton, R.; Serafini, M.; Delmulle, L. Project BELFRIT: Harmonizing the Use of Plants in Food Supplements in the European Union: Belgium, France and Italy-AFirst Step. Eur. Food Feed Law 2013, 8, 187-196.

2. Regulation (EC) No 258/97 of the European Parliament and of the Council of 27 January 1997 Concerning Novel Foods and Novel Food Ingredients; EC: Brussels, Belgium, 1997; pp. 1-6. 
3. 2008/558/EC: Commission Decision of 27 June 2008 Authorising the Placing on the Market of Refined Echium Oil as Novel Food Ingredient under Regulation (EC) No 258/97 of the European Parliament and of the Council; EC: Brussels, Belgium, 2008; pp. 17-19.

4. Commission Decision 2000/196/EC of 22 February 2000 Refusing the Placing on the Market of Stevia Rebaudiana Bertoni: Plants and Dried Leaves' as a Novel Food or Novel Food Ingredient under Regulation No 258/97; EC: Brussels, Belgium, 2000; p. 14.

5. Directive 2002/46/EC of the European Parliament and of the Council of 10 June 2002 on the Approximation of the Laws of the Member States Relating to Food Supplements; EC: Brussels, Belgium, 2002; pp. 51-57.

6. Committee on Herbal Medicinal Products (HMPC) European Union Herbal Monograph on Hedera Helix L., Folium; 24 November 2015EMA/HMPC/586888/2014. Available online: http://www.ema.europa.eu/docs/en_ GB/document_library/HerbalHerbal_monograph/2016/01/WC500199890.pdf (accessed on 18 December 2020).

7. Maione, F.; Russo, R.; Kha, H.; Mascolo, N. Medicinal plants with anti-inflammatory activities. Nat. Prod. Res. 2016, 12, 1343-1352. [CrossRef] [PubMed]

8. Izzo, A.A.; Teixeira, M.; Alexander, S.P.H.; Cirino, G.; Docherty, J.R.; George, C.H.; Insel, P.A.; Ji, Y.; Kendall, D.A.; Panattieri, R.A.; et al. A practical guide for transparent reporting of research on natural products in the British Journal of Pharmacology: Reproducibility of natural product research. Br. J. Pharmacol. 2020, 10, 2169-2178. [CrossRef] [PubMed]

9. López-Varela, S.; González-Gross, M.; Marcos, A. Functional foods and the immune system: A review. Eur. J. Clin. Nutr. 2002, 56, S29-S33. [CrossRef] [PubMed]

10. Granado-Lorencio, F; Hernández-Alvarez, E. Functional Foods and Health Effects: A Nutritional Biochemistry Perspective. Curr. Med. Chem. 2016, 23, 2929-2957. [CrossRef]

11. Gul, K.; Singh, A.K.; Jabeen, R. Nutraceuticals and Functional Foods: The Foods for the Future World. Crit. Rev. Food Sci. Nutr. 2016, 16, 2617-2627. [CrossRef]

12. Thomford, N.E.; Senthebane, D.A.; Rowe, A.; Munro, D.; Seele, P.; Maroyi, A.; Dzobo, K. Natural Products for Drug Discovery in the 21st Century: Innovations for Novel Drug Discovery. Int. J. Mol. Sci. 2018, 19, 1578. [CrossRef]

13. Hoyles, L.; Vulevic, J. Diet, immunity and functional foods. Adv. Exp. Med. Biol. 2008, 635, 79-92. [CrossRef]

14. Sattigere, V.D.; Kumar, P.R.; Prakash, V. Science-based regulatory approach for safe nutraceuticals. J. Sci. Food Agric. 2020, 14, 5079-5082. [CrossRef]

15. Mora, J.R.; Iwata, M.; von Andrian, U.H. Vitamin effects on the immune system: Vitamins A and D take centre stage. Nat. Rev. Immunol. 2008, 9, 685-698. [CrossRef]

16. Ding, S.; Jiang, H.; Fang, J. Regulation of Immune Function by Polyphenols. J. Immunol. Res. 2018, $2018,1264074$. [CrossRef] [PubMed]

17. Jones, P.J.; Varady, K.A. Are functional foods redefining nutritional requirements? Appl. Physiol. Nutr. Metab. 2008, 1, 118-123. [CrossRef] [PubMed]

18. Eussen, S.R.; Verhagen, H.; Klungel, O.H.; Garssen, J.; van Loveren, H.; van Kranen, H.J.; Rompelberg, C.J. Functional foods and dietary supplements: Products at the interface between pharma and nutrition. Eur. J. Pharmacol. 2011, 668, S2-S9. [CrossRef] [PubMed]

19. Domínguez, D.L.; Fernández-Ruiz, V.; Cámara, M. The frontier between nutrition and pharma: The international regulatory framework of functional foods, food supplements and nutraceuticals. Food Sci. Nutr. 2020, 10, 1738-1746. [CrossRef]

20. Aronson, J.K. Defining 'nutraceuticals': Neither nutritious nor pharmaceutical. Br. J. Clin. Pharmacol. 2017, 1, 8-19. [CrossRef]

21. Santini, A.; Novellino, E. To Nutraceuticals and Back: Rethinking a Concept. Foods 2017, 6, 74. [CrossRef]

22. Adefegha, S.A. Functional Foods and Nutraceuticals as Dietary Intervention in Chronic Diseases; Novel Perspectives for Health Promotion and Disease Prevention. J. Diet. Suppl. 2018, 6, 977-1009. [CrossRef]

23. Santini, A.; Cammarata, S.M.; Capone, G.; Ianaro, A.; Tenore, G.C.; Pani, L.; Novellino, E. Nutraceuticals: Opening the debate for a regulatory framework. Br. J. Clin. Pharmacol. 2018, 4, 659-672. [CrossRef]

24. Daliu, P.; Santini, A.; Novellino, E. From pharmaceuticals to nutraceuticals: Bridging disease prevention and management. Expert. Rev. Clin. Pharmacol. 2019, 12,1-7. [CrossRef] 
25. Sultan, M.T.; Butt, M.S.; Qayyum, M.M.; Suleria, H.A. Immunity: Plants as effective mediators. Food Sci. Nutr. 2014, 10, 1298-1308. [CrossRef]

26. Wu, D.; Lewis, E.D.; Pae, M.; Meydani, S.N. Nutritional Modulation of Immune Function: Analysis of Evidence, Mechanisms, and Clinical Relevance. Front. Immunol. 2019, 15, 3160. [CrossRef] [PubMed]

27. Soehnlein, O.; Lindbom, L. Phagocyte partnership during the onset and resolution of inflammation. Nat. Rev. Immunol. 2010, 6, 427-439. [CrossRef] [PubMed]

28. Sun, S.; Ji, Y.; Kersten, S.; Qi, L. Mechanisms of inflammatory responses in obese adipose tissue. Annu. Rev. Nutr. 2012, 32, 261-286. [CrossRef] [PubMed]

29. Sugimoto, M.A.; Sousa, L.P.; Pinho, V.; Perretti, M.; Teixeira, M.M. Resolution of Inflammation: What Controls Its Onset? Front. Immunol. 2016, 7, 160. [CrossRef] [PubMed]

30. Perretti, M.; D'Acquisto, F. Annexin A1 and glucocorticoids as effectors of the resolution of inflammation. Nat. Rev. Immunol. 2009, 9, 62-70. [CrossRef] [PubMed]

31. D'Acquisto, F.; Maione, F.; Pederzoli-Ribeil, M. From IL-15 to IL-33: The never-ending list of new players in inflammation. Is it time to forget the humble aspirin and move ahead? Biochem. Pharmacol. 2010, 79, 525-534. [CrossRef] [PubMed]

32. Cooper, M.D.; Alder, M.N. The evolution of adaptive immune systems. Cell 2006, 124, 815-822. [CrossRef]

33. Varela, M.L.; Mogildea, M.; Moreno, I.; Lopes, A. Acute Inflammation and Metabolism. Inflammation 2018, 4, 1115-1127. [CrossRef]

34. Perretti, M.; Cooper, D.; Dalli, J.; Norling, L.V. Immune resolution mechanisms in inflammatory arthritis. Nat. Rev. Rheumatol. 2017, 13, 87-99. [CrossRef]

35. Ge, Y.; Huang, M.; Yao, Y.M. Autophagy and Proinflammatory Cytokines: Interactions and Clinical Implications. Cytokine Growth Factor Rev. 2018, 43, 38-46. [CrossRef]

36. Medzhitov, R. Origin and Physiological Roles of Inflammation. Nature 2008, 7203, 428-435. [CrossRef] [PubMed]

37. Higgs, G.A.; Moncada, S.; Vane, J.R. Eicosanoids in inflammation. Ann. Clin. Res. 1984, 16, 287-299. [PubMed]

38. Serhan, C.N. Pro-resolving lipid mediators are leads for resolution physiology. Nature 2014, 510, 92-101. [CrossRef] [PubMed]

39. Serhan, C.N.; Chiang, N.; Dalli, J. The resolution code of acute inflammation: Novel pro-resolving lipid mediators in resolution. Semin. Immunol. 2015, 3, 200-215. [CrossRef] [PubMed]

40. Murakami, M.; Naraba, H.; Tanioka, T.; Semmyo, N.; Nakatani, Y.; Kojima, F.; Ikeda, T.; Fueki, M.; Ueno, A.; $\mathrm{Oh}, \mathrm{S}$. Regulation of prostaglandin E2 biosynthesis by inducible membrane-associated prostaglandin E2 synthase that acts in concert with cyclooxygenase-2. J. Biol. Chem. 2000, 32783-33279. [CrossRef]

41. Stichtenoth, D.O.; Thorén, S.; Bian, H.; Peters-Golden, M.; Jakobsson, P.J.; Crofford, L.J. Microsomal prostaglandin E synthase is regulated by proinflammatory cytokines and glucocorticoids in primary rheumatoid synovial cells. J. Immunol. 2001, 167, 469-474. [CrossRef]

42. Saegusa, M.; Murakami, M.; Nakatani, Y.; Yamakawa, K.; Katagiri, M.; Matsuda, K.; Kawaguchi, H. Contribution of membrane-associated prostaglandin E2 synthase to bone resorption. J. Cell. Physiol. 2003, 197, 348-356. [CrossRef]

43. Li, X.; Afif, H.; Cheng, S.; Martel-Pelletier, J.; Pelletier, J.P.; Ranger, P.; Fahmi, H. Expression and regulation of microsomal prostaglandin E synthase-1 in human osteoarthritic cartilage and chondrocytes. J. Rheumatol. 2005, 32, 887-895.

44. Samuelsson, B.; Morgenstern, R.; Jakobsson, P.J. Membrane prostaglandin E synthase-1: A novel therapeutic target. Pharmacol. Rev. 2007, 3, 207-224. [CrossRef]

45. Koeberle, A.; Werz, O. Perspective of microsomal prostaglandin E2 synthase-1 as drug target in inflammation-related disorders. Biochem. Pharmacol. 2015, 1, 1-15. [CrossRef]

46. Raucci, F.; Iqbal, A.J.; Saviano, A.; Minosi, P.; Piccolo, M.; Irace, C.; Caso, F.; Scarpa, R.; Pieretti, S.; Mascolo, N.; et al. IL-17A neutralizing antibody regulates monosodium urate crystal-induced gouty inflammation. Pharmacol. Res. 2019, 147, 104351. [CrossRef] [PubMed]

47. Maione, F.; Casillo, G.M.; Raucci, F.; Iqbal, A.J.; Mascolo, N. The functional link between microsomal prostaglandin E synthase-1 (mPGES-1) and peroxisome proliferator-activated receptor $\gamma$ (PPAR $\gamma$ ) in the onset of inflammation. Pharmacol. Res. 2020, 157, 104807. [CrossRef] [PubMed] 
48. Chang, H.H.; Meuillet, E.J. Identification and development of mPGES-1 inhibitors: Where we are at? Future Med. Chem. 2011, 15, 1909-1934. [CrossRef]

49. Koeberle, A.; Werz, O. Inhibitors of the microsomal prostaglandin E (2) synthase-1 as alternative to non steroidal anti-inflammatory drugs (NSAIDs) - A critical review. Curr. Med. Chem. 2009, 32, 4274-4496. [CrossRef] [PubMed]

50. Bergqvist, F.; Morgenstern, R.; Jakobsson, P.J. A review on mPGES-1 inhibitors: From preclinical studies to clinical applications. Prostaglandins Other Lipid Mediat. 2020, 147, 106383. [CrossRef] [PubMed]

51. Koeberle, A.; Bauer, J.; Verhoff, M.; Hoffmann, M.; Northoff, H.; Werz, O. Green tea epigallocatechin-3-gallate inhibits microsomal prostaglandin E(2) synthase-1. Biochem. Biophys. Res. Comm. 2009, 2, 350-354. [CrossRef]

52. Koeberle, A.; Northoff, H.; Werz, O. Curcumin blocks prostaglandin E2 biosynthesis through direct inhibition of the microsomal prostaglandin E2 synthase-1. Mol. Cancer Ther. 2009, 8, 2348-2355. [CrossRef]

53. Siemoneit, U.; Koeberle, A.; Rossi, A.; Dehm, F.; Verhoff, M.; Reckel, S.; Maier, T.J.; Jauch, J.; Northoff, H.; Bernhard, F.; et al. Inhibition of microsomal prostaglandin E2 synthase-1 as a molecular basis for the anti-inflammatory actions of boswellic acids from frankincense. Br. J. Pharmacol. 2011, 162, 147-162. [CrossRef]

54. Yahfoufi, N.; Alsadi, N.; Jambi, M.; Matar, C. The Immunomodulatory and Anti-Inflammatory Role of Polyphenols. Nutrients 2018, 11, 1618. [CrossRef]

55. Cui, L.; Feng, L.; Zhang, Z.H.; Jia, X.B. The anti-inflammation effect of baicalin on experimental colitis through inhibiting TLR4/NF-кB pathway activation. Int. Immunopharmacol. 2014, 23, 294-303. [CrossRef]

56. Wang, C.; Song, Y.; Wang, X.; Mao, R.; Song, L. Baicalin Ameliorates Collagen-Induced Arthritis through the Suppression of Janus Kinase 1 (JAK1)/Signal Transducer and Activator of Transcription 3 (STAT3) Signaling in Mice. Med. Sci. Monit. 2018, 24, 9213-9222. [CrossRef] [PubMed]

57. Zhong, X.; Surh, Y.J.; Do, S.G.; Shin, E.; Shim, K.S.; Lee, C.K.; Na, H.K.J. Baicalein Inhibits Dextran Sulfate Sodium-induced Mouse Colitis. Cancer Prev. 2019, 24, 129-138. [CrossRef] [PubMed]

58. Chen, B.; Li, H.; Ou, G.; Ren, L.; Yang, X.; Zeng, M. Curcumin attenuates MSU crystal-induced inflammation by inhibiting the degradation of $\mathrm{I} \kappa \mathrm{B} \alpha$ and blocking mitochondrial damage. Arthritis Res. Ther. 2019, 2, 193. [CrossRef] [PubMed]

59. Moon, D.O.; Kim, M.O.; Choi, Y.H.; Park, Y.M.; Kim, G.Y. Curcumin attenuates inflammatory response in IL-1beta-induced human synovial fibroblasts and collagen-induced arthritis in mouse model. Int. Immunopharmacol. 2010, 10, 605-610. [CrossRef]

60. He, W.; Li, Y.; Liu, M.; Yu, H.; Chen, Q.; Chen, Y.; Ruan, J.; Ding, Z.; Zhang, Y.; Wang, T. Citrus aurantium L. and Its Flavonoids Regulate TNBS-Induced Inflammatory Bowel Disease through Anti-Inflammation and Suppressing Isolated Jejunum Contraction. Int. J. Mol. Sci. 2018, 19, 3057. [CrossRef]

61. Rosillo, M.A.; Sanchez-Hidalgo, M.; Cárdeno, A.; de la Lastra, C.A. Protective effect of ellagic acid, a natural polyphenolic compound, in a murine model of Crohn's disease. Biochem. Pharmacol. 2011, 82, 737-745. [CrossRef]

62. Marín, M.; Giner, R.M.; Ríos, J.L.; Recio Mdel, C. Protective effect of apocynin in a mouse model of chemically-induced colitis. Planta Med. 2013, 79, 1392-1400. [CrossRef]

63. Hwang, Y.J.; Nam, S.J.; Chun, W.; Kim, S.I.; Park, S.C.; Kang, C.D.; Lee, S.J. Anti-inflammatory effects of apocynin on dextran sulfate sodium-induced mouse colitis model. PLoS ONE 2019, 14, e0217642. [CrossRef]

64. Yang, L.; Shen, L.; Li, Y.; Li, Y.; Yu, S.; Wang, S. Hyperoside attenuates dextran sulfate sodium-induced colitis in mice possibly via activation of the Nrf2 signalling pathway. J. Inflamm. 2017, 14, 25. [CrossRef]

65. Dou, W.; Zhang, J.; Ren, G.; Ding, L.; Sun, A.; Deng, C.; Wu, X.; Wei, X.; Mani, S.; Wang, Z. Mangiferin attenuates the symptoms of dextran sulfate sodium-induced colitis in mice via NF-KB and MAPK signaling inactivation. Int. Immunopharmacol. 2014, 23, 170-178. [CrossRef]

66. Lee, I.A.; Hyun, Y.J.; Kim, D.H. Berberine ameliorates TNBS-induced colitis by inhibiting lipid peroxidation, enterobacterial growth and NF-kB activation. Eur. J. Pharmacol. 2010, 648, 162-170. [CrossRef] [PubMed]

67. Rocha, L.W.; Bonet, I.J.M.; Tambeli, C.H.; de-Faria, F.M.; Parada, C.A. Local administration of mangiferin prevents experimental inflammatory mechanical hyperalgesia through CINC-1/epinephrine/PKA pathway and TNF- $\alpha$ inhibition. Eur. J. Pharmacol. 2018, 830, 87-94. [CrossRef] [PubMed]

68. Chen, X.; Shen, J.; Zhao, J.M.; Guan, J.; Li, W.; Xie, Q.M.; Zhao, Y.Q. Cedrol attenuates collagen-induced arthritis in mice and modulates the inflammatory response in LPS-mediated fibroblast-like synoviocytes. Food Funct. 2020, 11, 4752-4764. [CrossRef] [PubMed] 
69. Liu, Y.; Duan, C.; Chen, H.; Wang, C.; Liu, X.; Qiu, M.; Tang, H.; Zhang, F.; Zhou, X.; Yang, J. Inhibition of COX-2/mPGES-1 and 5-LOX in macrophages by leonurine ameliorates monosodium urate crystal-induced inflammation. Toxicol. Appl. Pharmacol. 2018, 351,1-11. [CrossRef]

70. Li, H.; Gong, X.; Zhang, L.; Zhang, Z.; Luo, F.; Zhou, Q.; Chen, J.; Wan, J. Madecassoside attenuates inflammatory response on collagen-induced arthritis in DBA/1 mice. Phytomedicine 2009, 16, 538-546. [CrossRef]

71. Song, J.H.; Lee, J.W.; Shim, B.; Lee, C.Y.; Choi, S.; Kang, C.; Sohn, N.W.; Shin, J.W. Glycyrrhizin alleviates neuroinflammation and memory deficit induced by systemic lipopolysaccharide treatment in mice. Molecules 2013, 18, 15788-15803. [CrossRef]

72. Wang, H.L.; Li, Y.X.; Niu, Y.T.; Zheng, J.; Wu, J.; Shi, G.J.; Ma, L.; Niu, Y.; Sun, T.; Yu, J.Q. Observing Antiinflammatory and Anti-nociceptive Activities of Glycyrrhizin Through Regulating COX-2 and Pro-inflammatory Cytokines Expressions in Mice. Inflammation 2015, 38, 2269-2278. [CrossRef]

73. Maione, F.; Piccolo, M.; De Vita, S.; Chini, M.G.; Cristiano, C.; De Caro, C.; Lippiello, P.; Miniaci, M.C.; Santamaria, R.; Irace, C.; et al. Down regulation of pro-inflammatory pathways by tanshinone IIA and cryptotanshinone in a non-genetic mouse model of Alzheimer's disease. Pharmacol. Res. 2018, 129, 482-490. [CrossRef]

74. Zhang, F.X.; Xu, R.S. Juglanin ameliorates LPS-induced neuroinflammation in animal models of Parkinson's disease and cell culture via inactivating TLR4/NF-kB pathway. Biomed. Pharmacother. 2018, 97, 1011-1019. [CrossRef]

75. Halawany, A.M.E.; Sayed, N.S.E.; Abdallah, H.M.; Dine, R.S.E. Protective effects of gingerol on streptozotocininduced sporadic Alzheimer's disease: Emphasis on inhibition of $\beta$-amyloid, COX-2, alpha-, beta-secretases and APH1a. Sci. Rep. 2017, 7, 2902. [CrossRef]

76. Maione, F.; Cantone, V.; Pace, S.; Chini, M.G.; Bisio, A.; Romussi, G.; Pieretti, S.; Werz, O.; Koeberle, A.; Mascolo, N.; et al. Anti-inflammatory and analgesic activity of carnosol and carnosic acid in vivo and in vitro and in silico analysis of their target interactions. Br. J. Pharmacol. 2017, 174, 1497-1508. [CrossRef]

77. Chen, J.; Si, M.; Wang, Y.; Liu, L.; Zhang, Y.; Zhou, A.; Wei, W. Ginsenoside metabolite compound K exerts anti-inflammatory and analgesic effects via downregulating COX2. Inflammopharmacology 2019, 27, 157-166. [CrossRef] [PubMed]

78. Noack, M.; Miossec, P. Th17 and regulatory T cell balance in autoimmune and inflammatory diseases. Autoimmun. Rev. 2014, 13, 668-677. [CrossRef]

79. Zhu, J.; Paul, W.E. Peripheral CD4+ T-cell differentiation regulated by networks of cytokines and transcription factors. Immunol. Rev. 2010, 1, 247-262. [CrossRef] [PubMed]

80. Li, M.O.; Rudensky, A.Y. T cell receptor signalling in the control of regulatory T cell differentiation and function. Nat. Rev. Immunol. 2016, 4, 220-233. [CrossRef] [PubMed]

81. Ivanov, I.I.; McKenzie, B.S.; Zhou, L.; Tadokoro, C.E.; Lepelley, A.; Lafaille, J.J.; Cua, D.J.; Littman, D.R. The orphan nuclear receptor ROR gammat directs the differentiation program of proinflammatory IL-17+ T helper cells. Cell 2006, 6, 1121-1133. [CrossRef]

82. Bettelli, E.; Korn, T.; Oukka, M.; Kuchroo, V.K. Induction and effector functions of Th17 cells. Nature 2008, 453, 1051-1057. [CrossRef] [PubMed]

83. Samson, M.; Audia, S.; Janikashvili, N.; Ciudad, M.; Trad, M.; Fraszczak, J.; Ornetti, P.; Maillefert, J.F.; Miossec, P.; Bonnotte, B. Brief report: Inhibition of interleukin-6 function corrects Th17/Treg cell imbalance in patients with rheumatoid arthritis. Arthritis Rheum. 2012, 64, 2499-2503. [CrossRef]

84. Li, S.; Wu, Z.; Li, L.; Liu, X. Interleukin-6 IL-6 receptor antagonist protects against rheumatoid arthritis. Int. Med. J. Exp. Clin. Res. 2016, 22, 2113-2118. [CrossRef]

85. Fasching, P.; Stradner, M.; Graninger, W.; Dejaco, C.; Fessler, J. Therapeutic potential of targeting the Th17/Treg axis in autoimmune disorders. Molecules 2017, 22, 134. [CrossRef]

86. Cristiano, C.; Volpicelli, F.; Lippiello, P.; Buono, B.; Raucci, F.; Piccolo, M.; Iqbal, A.J.; Irace, C.; Miniaci, M.C.; Perrone Capano, C.; et al. Neutralization of IL-17 rescues amyloid- $\beta$-induced neuroinflammation and memory impairment. Br. J. Pharmacol. 2019, 18, 3544-3557. [CrossRef] [PubMed]

87. Raucci, F.; Iqbal, A.J.; Saviano, A.; Casillo, G.M.; Russo, M.; Lezama, D.; Mascolo, N.; Maione, F. In-depth immunophenotyping data relating to IL-17Ab modulation of circulating Treg/Th17 cells and of in situ infiltrated inflammatory monocytes in the onset of gouty inflammation. Data Brief. 2019, 25, 104381. [CrossRef] [PubMed] 
88. Littman, D.R.; Rudensky, A.Y. Th17 and regulatory T cells in mediating and restraining inflammation. Cell 2010, 6, 845-858. [CrossRef] [PubMed]

89. Bettelli, E.; Carrier, Y.; Gao, W.; Korn, T.; Strom, T.B.; Oukka, M.; Weiner, H.L.; Kuchroo, V.K. Reciprocal developmental pathways for the generation of pathogenic effector TH17 and regulatory T cells. Nature 2006, 7090, 235-238. [CrossRef]

90. Mangan, P.R.; Harrington, L.E.; O'Quinn, D.B.; Helms, W.S.; Bullard, D.C.; Elson, C.O.; Hatton, R.D.; Wahl, S.M.; Schoeb, T.R.; Weaver, C.T. Transforming growth factor-beta induces development of the T(H)17 lineage. Nature 2006, 7090, 231-234. [CrossRef]

91. Ivanov, I.I.; Zhou, L.; Littman, D.R. Transcriptional regulation of Th17 cell differentiation. Semin. Immunol. 2007, 6, 409-417. [CrossRef]

92. Zhou, L.; Chong, M.M.; Littman, D.R. Plasticity of CD4+ T cell lineage differentiation. Immunity 2009, 30, 646-655. [CrossRef]

93. Komatsu, N.; Okamoto, K.; Sawa, S.; Nakashima, T.; Oh-hora, M.; Kodama, T.; Tanaka, S.; Bluestone, J.A.; Takayanagi, H. Pathogenic conversion of Foxp3+ T cells into TH17 cells in autoimmune arthritis. Nat. Med. 2014, 20, 62-68. [CrossRef]

94. Gagliani, N.; Amezcua Vesely, M.C.; Iseppon, A.; Brockmann, L.; Xu, H.; Palm, N.W.; de Zoete, M.R.; Licona-Limon, P.; Paiva, R.S.; Ching, T.; et al. Th17 cells transdifferentiate into regulatory T cells during resolution of inflammation. Nature 2015, 523, 221-225. [CrossRef]

95. Boissier, M.C.; Assier, E.; Biton, J.; Denys, A.; Falgarone, G.; Bessis, N. Regulatory T Cells (Treg) in Rheumatoid Arthritis. J. Bone Spine. 2009, 76, 10-14. [CrossRef]

96. Chabaud, M.; Durand, J.M.; Buchs, N.; Fossiez, F.; Page, G.; Frappart, L.; Miossec, P. Human interleukin-17: A $\mathrm{T}$ cell-derived proinflammatory cytokine produced by the rheumatoid synovium. Arthritis Rheum. 1999, 42, 963-970. [CrossRef]

97. Wehrens, E.J.; Prakken, B.J.; van Wijk, F. T cells out of control-Impaired immune regulation in the inflamed joint. Nat. Rev. Rheumatol. 2013, 9, 34-42. [CrossRef] [PubMed]

98. Lee, S.Y.; Jung, Y.O.; Ryu, J.G.; Oh, H.J.; Son, H.J.; Lee, S.H.; Kwon, J.E.; Kim, E.K.; Park, M.K.; Park, S.H.; et al. Epigallocatechin-3-gallate ameliorates autoimmune arthritis by reciprocal regulation of T helper-17 regulatory T cells and inhibition of osteoclastogenesis by inhibiting STAT3 signaling. J. Leukoc. Biol. 2016, 3, 559-568. [CrossRef] [PubMed]

99. Zhang, S.; Liu, X.; Mei, L.; Wang, H.; Fang, F. Epigallocatechin-3-gallate (EGCG) inhibits imiquimod-induced psoriasis-like inflammation of BALB/c mice. BMC Complement. Altern. Med. 2016, 1, 334. [CrossRef] [PubMed]

100. Shan, L.; Kang, X.; Liu, F.; Cai, X.; Han, X.; Shang, Y. Epigallocatechin gallate improves airway inflammation through TGF- $\beta 1$ signaling pathway in asthmatic mice. Mol. Med. Rep. 2018, 18, 2088-2096. [CrossRef] [PubMed]

101. Xu, Z.; Wei, C.; Zhang, R.U.; Yao, J.; Zhang, D.; Wang, L. Epigallocatechin-3-gallate-induced inhibition of interleukin- 6 release and adjustment of the regulatory $\mathrm{T} / \mathrm{T}$ helper 17 cell balance in the treatment of colitis in mice. Exp. Ther. Med. 2015, 6, 2231-2238. [CrossRef]

102. Yang, N.; Shang, Y.X. Epigallocatechin gallate ameliorates airway inflammation by regulating Treg/Th17 imbalance in an asthmatic mouse model. Int. Immunopharmacol. 2019, 72, 422-428. [CrossRef]

103. Zou, Y.; Dai, S.X.; Chi, H.G.; Li, T.; He, Z.W.; Wang, J.; Ye, C.; Huang, G.L.; Zhao, B.; Li, W.Y.; et al. Baicalin attenuates TNBS-induced colitis in rats by modulating the Th17/Treg paradigm. Arch. Pharm. Res. 2015, 10, 1873-1887. [CrossRef]

104. Hu, C.A.; Hou, Y.; Yi, D.; Qiu, Y.; Wu, G.; Kong, X.; Yin, Y. Autophagy and tight junction proteins in the intestine and intestinal diseases. Anim. Nutr. 2015, 1, 123-127. [CrossRef]

105. Zhu, L.; Xu, L.Z.; Zhao, S.; Shen, Z.F.; Shen, H.; Zhan, L.B. Protective effect of baicalin on the regulation of Treg/Th17 balance, gut microbiota and short-chain fatty acids in rats with ulcerative colitis. Appl. Microbiol. Biotechnol. 2020, 104, 5449-5460. [CrossRef]

106. Ma, C.; Ma, Z.; Fu, Q.; Ma, S. Anti-asthmatic effects of baicalin in a mouse model of allergic asthma. Phytother. Res. 2014, 28, 231-237. [CrossRef] [PubMed] 
107. Xu, L.; Li, J.; Zhang, Y.; Zhao, P.; Zhang, X.J. Regulatory effect of baicalin on the imbalance of Th17/Treg responses in mice with allergic asthma. J. Ethnopharmacol. 2017, 208, 199-206. [CrossRef] [PubMed]

108. Yang, X.; Yang, J.; Zou, H. Baicalin inhibits IL-17-mediated joint inflammation in murine adjuvant-induced arthritis. Clin. Dev. Immunol. 2013, 2013, 268065. [CrossRef] [PubMed]

109. Ma, C.; Ma, Z.; Liao, X.L.; Liu, J.; Fu, Q.; Ma, S.J. Immunoregulatory effects of glycyrrhizic acid exerts anti-asthmatic effects via modulation of Th1/Th2 cytokines and enhancement of CD4(+)CD25(+)Foxp3+ regulatory T cells in ovalbumin-sensitized mice. J. Ethnopharmacol. 2013, 3, 755-762. [CrossRef]

110. Chen, X.; Fang, D.; Li, L.; Chen, L.; Li, Q.; Gong, F.; Fang, M. Glycyrrhizin ameliorates experimental colitis through attenuating interleukin-17-producing $\mathrm{T}$ cell responses via regulating antigen-presenting cells. Immunol. Res. 2017, 3, 666-680. [CrossRef]

111. Yun, C.; Chang, M.; Hou, G.; Lan, T.; Yuan,H.; Su,Z.; Zhu, D.; Liang,W.; Li, Q.; Zhu, H.; et al. Mangiferin suppresses allergic asthma symptoms by decreased Th9 and Th17 responses and increased Treg response. Mol. Immunol. 2019, 114, 233-242. [CrossRef]

112. Lim, S.M.; Kang, G.D.; Jeong, J.J.; Choi, H.S.; Kim, D.H. Neomangiferin modulates the Th17/Treg balance and ameliorates colitis in mice. Phytomedicine 2016, 23, 131-140. [CrossRef]

113. Chauhan, P.S.; Dash, D.; Singh, R. Intranasal curcumin attenuates airway remodeling in murine model of chronic asthma. Int. Immunopharmacol. 2014, 21, 63-75. [CrossRef]

114. Sun, J.; Zhao, Y.; Hu, J. Curcumin inhibits imiquimod-induced psoriasis-like inflammation by inhibiting IL-1beta and IL-6 production in mice. PLoS ONE 2013, 8, e67078. [CrossRef]

115. Ma, C.; Ma, Z.; Fu, Q.; Ma, S. Curcumin attenuates allergic airway inflammation by regulation of CD4+CD25+ regulatory T cells (Tregs)/Th17 balance in ovalbumin-sensitized mice. Fitoterapia 2013, 87, 57-64. [CrossRef]

116. Chen, H.; Lu, C.; Liu, H.; Wang, M.; Zhao, H.; Yan, Y.; Han, L. Quercetin ameliorates imiquimod-induced psoriasis-like skin inflammation in mice via the NF-кB pathway. Int. Immunopharmacol. 2017, 48, 110-117. [CrossRef] [PubMed]

117. Wang, Y.; Zhou, C.; Gao, H.; Li, C.; Li, D.; Liu, P.; Huang, M.; Shen, X.; Liu, L. Therapeutic effect of Cryptotanshinone on experimental rheumatoid arthritis through downregulating p300 mediated-STAT3 acetylation. Biochem. Pharmacol. 2017, 138, 119-129. [CrossRef] [PubMed]

118. Choi, J.K.; Kim, S.W.; Kim, D.S.; Lee, J.Y.; Lee, S.; Oh, H.M.; Ha, Y.S.; Yoo, J.; Park, P.H.; Shin, T.Y.; et al. Oleanolic acid acetate inhibits rheumatoid arthritis by modulating $\mathrm{T}$ cell immune responses and matrix-degrading enzymes. Toxicol. Appl. Pharmacol. 2016, 290, 1-9. [CrossRef] [PubMed]

119. Tong, B.; Dou, Y.; Wang, T.; Yu, J.; Wu, X.; Lu, Q.; Chou, G.; Wang, Z.; Kong, L.; Dai, Y.; et al. Norisoboldine ameliorates collagen-induced arthritis through regulating the balance between Th17 and regulatory $\mathrm{T}$ cells in gut-associated lymphoid tissues. Toxicol. Appl. Pharmacol. 2015, 28, 90-99. [CrossRef]

120. Li, C.; Xi, Y.; Li, S.; Zhao, Q.; Cheng, W.; Wang, Z.; Zhong, J.; Niu, X.; Chen, G. Berberine ameliorates TNBS induced colitis by inhibiting inflammatory responses and Th1/Th17 differentiation. Mol. Immunol. 2015, 67, 444-454. [CrossRef]

121. Urushima, H.; Nishimura, J.; Mizushima, T.; Hayashi, N.; Maeda, K.; Ito, T. Perilla frutescens extract ameliorates DSS-induced colitis by suppressing proinflammatory cytokines and inducing anti-inflammatory cytokines. Am. J. Physiol. Gastrointest. Liver Physiol. 2015, 308, G32-G41. [CrossRef]

122. Lim, S.M.; Jeong, J.J.; Kang, G.D.; Kim, K.A.; Choi, H.S.; Kim, D.H. Timosaponin AIII and its metabolite sarsasapogenin ameliorate colitis in mice by inhibiting NF-kB and MAPK activation and restoring Th17/Treg cell balance. Int. Immunopharmacol. 2015, 25, 493-503. [CrossRef]

123. Xu, X.; Wang, Y.; Wei, Z.; Wei, W.; Zhao, P.; Tong, B.; Xia, Y.; Dai, Y. Madecassic acid, the contributor to the anti-colitis effect of madecassoside, enhances the shift of Th17 toward Treg cells via the PPAR $\gamma /$ AMPK/ACC1 pathway. Cell Death Dis. 2017, 8, e2723. [CrossRef]

124. Chen, S.; Han, K.; Li, H.; Cen, J.; Yang, Y.; Wu, H.; Wei, Q.J. Isogarcinol Extracted from Garcinia mangostana L. Ameliorates Imiquimod-Induced Psoriasis-like Skin Lesions in Mice. Agric. Food Chem. 2017, 65, 846-857. [CrossRef]

125. Di, T.T.; Ruan, Z.T.; Zhao, J.X.; Wang, Y.; Liu, X.; Wang, Y.; Li, P. Astilbin inhibits Th17 cell differentiation and ameliorates imiquimod-induced psoriasis-like skin lesions in BALB/c mice via Jak3/Stat3 signaling pathway. Int. Immunopharmacol. 2016, 32, 32-38. [CrossRef] 
126. Sun, Y.; Zhang, J.; Huo, R.; Zhai, T.; Li, H.; Wu, P.; Zhu, X.; Zhou, Z.; Shen, B.; Li, N. Paeoniflorin inhibits skin lesions in imiquimod-induced psoriasis-like mice by downregulating inflammation. Int. Immunopharmacol. 2015, 24, 392-399. [CrossRef] [PubMed]

Publisher's Note: MDPI stays neutral with regard to jurisdictional claims in published maps and institutional affiliations.

(C) 2020 by the authors. Licensee MDPI, Basel, Switzerland. This article is an open access article distributed under the terms and conditions of the Creative Commons Attribution (CC BY) license (http://creativecommons.org/licenses/by/4.0/). 